\title{
Anthropogenic Pollution of Inland Waters: the Case of the Aboabo River in Kumasi, Ghana
}

\author{
Leslie Danquah (Corresponding author) \\ CASS, Faculty of Social Sciences, Department of Geography and Rural Development \\ Kwame Nkrumah University of Science and Technology \\ Kumasi, Ghana \\ Tel: 233-244-714-882Ｅ-mail: kwasileslie@yahoo.com
}

Kabila Abass

CASS, Faculty of Social Sciences, Department of Geography and Rural Development

Kwame Nkrumah University of Science and Technology

Kumasi, Ghana

Tel: 233-244-580-883Ｅ-mail: abakabila@yahoo.com

\author{
Aristotle A. Nikoi \\ Baron College
}

P.O. Box DS 1226, Dansoman, Accra, Ghana.

Tel: 233-277-442-737 E-mail: aristotlenikoi@yahoo.com

Received: September 20, 2011

Accepted: October 26, $2011 \quad$ Published: December 1, 2011

doi:10.5539/jsd.v4n6p103

URL: http://dx.doi.org/10.5539/jsd.v4n6p103

\begin{abstract}
This study assessed the quality of the Aboabo River and examined the anthropogenic factors that lead to river pollution. Physico-chemical and bacteriological assessment of water samples showed that water from the Aboabo river was polluted and therefore not suitable for domestic consumption. Observation, in-depth interviews, informal conversation and a cross-sectional survey of 396 households in the river basin were employed to elicit qualitative and quantitative data. Direct anthropogenic factors identified were indiscriminate dumping of refuse, channelling of raw sewage, open defecation and indiscriminate dumping of industrial waste into the Aboabo River. Remote factors identified were population growth and institutional challenges. Recommendations made include enforcement of by-laws, provision of adequate sanitation facilities and the encouragement of opinion leaders to play an active role in promoting the inculcation of environmentally friendly practices amongst residents.
\end{abstract}

Keywords: Anthropogenic factors, Water quality, River pollution, River basin

\section{Introduction}

Water is life. Without water, man's existence on the earth would be threatened and he would be driven close to extinction. Early civilizations flourished along the Nile, Tigris and Euphrates in ancient Mesopotamia, Indus in India, and Huang He in China due to their location near water sources (Ayoade, 1988). In the early days of man's existence the amount of waste he generated was small. It was disposed off locally and had virtually no effect upon the environment. Later, when larger human settlements and towns were established, waste disposal began to cause obvious pollution of streets and water courses (Dix, 1981).

According to UNESCO (2003), some 2 million tons of waste per day are disposed off within receiving waters, including industrial wastes and chemicals, human waste and agricultural wastes such as fertilizers, pesticides and pesticide residues. The waste management and sanitation situation in Ghana is quite precarious. According to Obuobie et al. (2006), about 20 percent of households in Ghana have no toilets with the percentage increasing to about 70 for the three Northern Regions. In addition, only 5 percent of the population disposes their liquid waste 
through sewage networks connected to treatment plants, 38 percent throw liquid waste on the streets whilst 21 percent throw it directly into gutters. Furthermore, 35 percent dispose liquid waste in the compound and 1 percent in other places. In the Kumasi metropolis, it is not uncommon to see waste tips located at the edge of river banks or in the river course.

Rivers in the Kumasi metropolis are noted to be polluted through human activity (Nsiah Gyabaah, 2001; CEDAR, 1999; Cornish et al., 1999; McGregor et al., 2003). Recent research evidence showed that the Aboabo River was the most polluted river in Kumasi whilst the least polluted was the Wiwi (Omane, 2002). However reviewed literature revealed that information on the sources or causes of pollution of the Aboabo River in particular was limited. Therefore this study sought to fill this gap. First, by assessing the water quality of the Aboabo River and examining the anthropogenic factors that were responsible for pollution.

\section{Methods}

\subsection{Study area}

The study was conducted in Kumasi, the capital of the Ashanti region of Ghana. The Kumasi metropolis is densely populated. It has the second largest urban economy in Ghana attracting trade and commerce in industry, services and government administrative functions (KMA, 2006). Population density of the Kumasi metropolis was recorded as 5319 persons per sq $\mathrm{km}$ in the 2000 Ghana Population and housing census. This was second to that of Accra, the capital of Ghana, which recorded at 5,530 in 2000 (GSS, 2005).

The Aboabo River Basin (Figure 1) has a very large percentage of the population of the metropolis. In 1984 and 2000 the population of the basin was 95189 and 251510 respectively. By the year 2000, the population had more than doubled, about 2.6 times that of the population in 1984. It is estimated that about 449692 persons live in the basin approximating a quarter of the total population (23\%) of the Kumasi metropolis (Danquah, 2010).

The Aboabo River (Figure 2) originates from Tafo-Pankrono at the northern part of the Kumasi Metropolis. It flows through Moshie Zongo, Buokrom, to Aboabo, Anloga and joins the Sisa at a confluence at Asokwa. At varied points, the Aboabo River yields an average speed of $0.87 \mathrm{~m} / \mathrm{s}$ (Omane, 2002).

A reconnaissance survey was conducted in the Aboabo River Basin from September - November, 2008 and this was followed with a cross-sectional survey of 396 households living within 7 communities that lie in the Aboabo River Basin (Table 1). The absence of a sampling frame prompted the calculation of a minimum sample for each community (Saunders et al., 2007). Households living within 0-100m of the Aboabo River were selected using a simple random sampling technique in each community.

A mixed methods approach was adopted for data collection. We triangulated methods such as interviewer administered questionnaires, observation, formal and informal interviews and informal conversations with residents. Official perspectives were drawn from formal interviews with officers of the Kumasi Metropolitan Assembly (KMA) and the Environmental Protection Agency (EPA), Kumasi office.

\subsection{Water Sampling}

Water quality analyses were carried out on water samples collected in December 2008 and January, 2009 (Dry season). Each sampling site was visited once in a month. Two (2) $500 \mathrm{ml}$ bottles were filled with water samples from each sampling site. Temperature was recorded on site and thereafter, the samples were placed on ice and transported to the UNESCO IHE Laboratory, Department of Civil Engineering, KNUST for analysis. Parameters that were examined include Temperature, Color, Electrical Conductivity, Hardness, pH, Dissolved Oxygen (DO), Biochemical Oxygen Demand (BOD), Chemical Oxygen Demand (COD), Total Dissolved Solids (TDS), Total Suspended Solids (TSS), Sulphate, Nitrate, Calcium, Magnesium and Faecal coliform.

\section{Results and Discussions}

\subsection{Physical characteristics of Aboabo Water Quality}

The water sampled from the Aboabo River was dark grey in colour. Table 2 shows the Color (Hazen's H) of the water sampled. The WHO (2006) prescribes that water for drinking should have no visible colour thus the water was not acceptable to residents for domestic consumption. The low Dissolved Oxygen (DO) content indicated the possibility of increased bacterial activity in the river water.

\subsection{Chemical Characteristics}

Table 3 shows that three (3) out of nine (9) chemical parameters exceeded Ghana Environmental Protection Agency (GEPA) guidelines and these were BOD, COD and Total Suspended Solids (TSS). High BOD and COD values meant that there was the likelihood of pollution through discharge of organic wastes like refuse, human 
and animal excreta into the river (Abdul-Razak, 2009). Furthermore, low DO, high values of BOD and COD at the sampling sites indicated that the water had a low potential to support aquatic life such as fish (Meyer \& Barclay, 1990). GEPA Guideline for TSS was also exceeded at all sampling stations giving an indication that the river was polluted.

\subsection{Bacteriological water quality}

The WHO prescribes a guideline value of 0 for faecal bacteria in drinking water (UNICEF, 2008). Average faecal coliform count for the sampling sites exceeded the maximum limit of 0 per $100 \mathrm{ml}$ as given by the WHO. In their 1999 review of students' thesis, Cornish et al. (1999) recorded that the Aboabo River had an average faecal coliform value of $1.3 \times 10^{6} / 100 \mathrm{ml}$. Danquah (2010) also recorded a higher average faecal coliform value of $3.5 \times 10^{6} / 100 \mathrm{ml}$. The bacteriological analysis pointed to a degradation of water quality in the Aboabo River with large amounts of faecal coliform indicating possible pollution from human sources (Table 4).

\subsection{Anthropogenic factors}

\subsubsection{Indiscriminate dumping of refuse into the Aboabo River}

First among anthropogenic factors identified was the indiscriminate dumping of refuse into the Aboabo River. Waste generation is an inevitable by-product of consumption. However the disposal of refuse poses a challenge especially where waste disposal facilities are inadequate. Households $(64 \%)$ disposed their refuse in environmentally unfriendly ways (Table 5). These included uncontrolled burning (5\%), burying (4\%), dumping into open space (11\%) and dumping into or near the Aboabo River (44\%).

Dumping of refuse in the river basin was most often done by the female child in $88 \%$ of households. Observations showed that children disposed refuse on waste tips that were located on the banks of the Aboabo River. When asked why residents disposed refuse daily on the banks of the Aboabo River, the following were some of the responses given by the respondents.

'Some of the children live far from the dump sites and they (children) dump garbage into the river so that they do not get late for school' ('Elderly' woman, personal communication, September, 2009).

'Everybody is doing it' (Male trader, personal communication, September, 2009).

An 'elderly' woman living in Buokrom in an informal interview also said that

'When it rains all the garbage are washed downstream' (personal communication, September, 2009).

Essentially, distance, financial constraints and the perception of a wide acceptance of inappropriate waste disposal behaviour served as motivators for indiscriminate dumping of refuse along the banks of the Aboabo River. Other households (5\%) opted to contract private individuals to collect household waste at a fee. Observations showed that the individual waste collectors, in some cases, dumped the waste collected at the banks of the river. The dumping of refuse along the banks of the river constituted a significant point source of pollution.

\subsection{2 'Channelling' of raw sewage into the Aboabo River}

'Channelling' was defined as the deliberate use of sewage pipes, that have been laid directly into the river, as a means of disposing liquid waste. It also included the direct pouring of faeces from bucket latrines into the Aboabo River. Seventy two (72\%) households primarily disposed of human excreta using septic tanks. $13.4 \%$ disposed into gutters which lead into the Aboabo River. A worrying trend identified was the connection of PVC pipes into the river directly from house drains. Six $(6 \%)$ of households surveyed disposed of excreta by means of 'channelling' it directly into the Aboabo River by means of PVC pipes.

The use of 'Bucket latrines' have been banned by the KMA. However $2 \%$ of households used 'Bucket latrines' and disposed excreta directly into the Aboabo River (Table 6). All households that used the bucket latrine contracted individuals to empty them daily into the Aboabo River very early in the mornings. This provided evidence of a breach of KMA bye-laws (KMA, 1998). Daily pouring of faeces served as a significant point source of pollution to the Aboabo River and contributed to the high faecal coliform count recorded in earlier studies on the Aboabo river water (Omane, 2002; Danquah, 2010). Other means included usage of public toilets (16\%), open defecation (2\%) and usage of water closets connected to septic tanks (80\%) probably due to the absence of a comprehensive sewage system in the river basin.

In some cases, households (2\%) disposed children's' stools by throwing directly into the river. This practice had negative implications for water quality. This is because children's faeces are more likely to contain diarrhoeal 
pathogens that adult faeces (UNICEF, 2008). The daily channelling of excreta into the Aboabo River contributed to the high faecal coliform counts recorded and the consequent lowering of the DO content of the river.

\subsubsection{Open defecation along the banks of the river.}

Open defecation along the banks of the river was a common observable phenomenon. However when respondents were asked if they practiced open defecation, only $2 \%$ answered in the affirmative. The following are some of the reasons cited by respondents when they were asked about the reasons why 'others' openly defecated.

(1) Long queues experienced in the mornings at the public toilets.

(2) Queues in their homes due to inadequate toilets.

(3) Households find it difficult to pay 5pesewas/per person per visit to the public toilet.

A 5 member household will pay 25 pesewas per visit in the morning. For the week this amounts to Ghe 1.75 and GhC7.00 per month for morning visits alone. The average household size in the basin is 7.8 whilst the average number of households living in a house is 7.5 (Danquah, 2010) which is higher than that of the entire Kumasi metropolis (3.4 households per house). Expenses incurred by the household on daily visits to the public latrines were added to total household expenditure and for low income households this was difficult to pay. Thus defecating by the river bank was the more economic and in some cases the healthier option. This was echoed by a carpenter living in Aboabo who said that

'I cannot afford to pay for the food I eat and also pay for the waste that I have to clear out of my system' (personal communication, September, 2009).

\subsubsection{Discharge of untreated effluents into the Aboabo River.}

Untreated effluents were identified to be waste water from baths and domestic activities like cooking and washing. Evidence revealed that some households used public baths and disposed waste water from domestic activities separately.

Gutters served as the major means of disposal of waste water because over $70 \%$ of the households surveyed in the river basin used it as a primary means of disposing waste water from their baths and domestic activities. Field observation and interviews held with the metropolitan sanitation engineers revealed that the gutters (drains) used by households to dispose waste water had their terminal points in the river at various sections in the river basin. Whenever waste water was disposed into gutters they flowed directly into the Aboabo River constituting a very significant point source of pollution (Figure 4). The high BOD values (Table 3) are 'indicators of a high concentration of organic matter that are usually from waste water discharges' (Shaw, 1994). The case of liquid waste disposal into the Aboabo River is akin to that of New Delhi in India where only half of the 3billion litres of waste water is treated whilst the rest is disposed untreated into the Yamuna River (UNICEF, 2008)

\subsubsection{Indiscriminate dumping of industrial waste into the Aboabo River.}

Industrial activities along the banks of the river contributed to the pollution of the Aboabo River by introducing varied amounts of suspended solids, particulate matter and chemicals such as lead, mercury, nitrates, sulphates and phosphates. Observations showed that small scale industries were situated on the banks of the Aboabo River. Entrepreneurs running such businesses used the river as a source of water and a dumping ground for the waste generated. Examples of such small scale informal industries were a leather tanning industry at Aboabo, Palm Oil processing industry at Moshie Zongo (Upstream) and Ahensan (Downstream). Washing bays were situated close to the river before it entered the Aboabo community. These washing bays did not have paved or cemented compounds. Waste water from the washing bays drained directly into the river. Also, the wood industry at Anloga was a huge threat to the quality of water of the Aboabo River (Figure 5).

Midstream at Anloga, the wood entrepreneurs used the banks of the river as dumping grounds for saw dust and wood waste. Portions of the saw dust got carried by the river and this contributed to the total suspended solids in the river water. A charcoal producing industry had also emerged behind the Anloga wood processing centre. These charcoal producers took advantage of the wood waste products and process them into charcoal. Unfortunately, this industry was situated on the banks of the river. When it rained heavily, runoff introduced washed sawdust, charcoal, sediment, soot and nutrients into the river affecting colour and turbidity (Hroncich, 1999). 


\section{Remote Factors}

Population growth and institutional challenges were identified as remote factors inducing anthropogenic activity that led to the pollution of the Aboabo River. The population of the river basin was estimated at 33396 in 1970 and 204049 in 2000. The population of the Aboabo river basin held about $24 \%$ of the total population of the Kumasi metropolis yet a comprehensive sewage system was non-existent in the river basin (Danquah, 2010).

Rapid population growth in the Aboabo River Basin had far outstretched the KMA's ability to manage liquid and solid waste (A. Adjei-Boateng, personal communication, September, 2009). Residents therefore resorted to the use of unsanitary public toilets, build toilets connected to septic tanks, channel raw sewage into the Aboabo River, practice open defecation along the river bank or at best alternate amongst the means at their disposal. This confirms Hardoy, Mitlin and Satterthwaite (2001)'s assertion that in the absence of comprehensive waste collection and disposal, much of liquid and solid wastes from households and businesses end up in rivers greatly increasing biochemical oxygen demand.

Coupled with population growth are institutional challenges faced by major stakeholders such as the KMA and EPA. These challenges include poor enforcement of by-laws which prohibits open defecation, indiscriminate dumping of refuse into water courses and the use of bucket latrines (KMA, 1998). In addition, poor regulation and monitoring of building regulations has afforded some land lords in the Aboabo River Basin the opportunity to convert their toilets and baths into rooms in order to cash in on the high demand for accommodation. Thus residents were forced to make alternate arrangements for solid and liquid waste disposal (Field Observation, 2009). Furthermore financial constrains limit the KMA and EPA's ability to provide adequate sanitation facilities in the metropolis carry out regular comprehensive water quality monitoring and employ adequate numbers of sanitary inspectors on a regular basis (A. Adjei-Boateng, personal communication, September, 2009). The inter-play of the remote factors induces anthropogenic activity that leads to the pollution of the Aboabo River.

\section{Implications}

During the course of this study, there was no evidence that suggested that the river was used for domestic purposes. However, accounts from the elderly indicated that it was 'clean' and used for domestic purposes in the 1950s'. Thus impairment of the Aboabo River had created a denial of amenity. Residents living in the river basin and downstream in Asago recounted in the reconnaissance survey that members of the community previously fetched water from the river for domestic purposes. Others indicated that they would use the water for domestic purposes if it was 'clean'.

Secondly, evidence pointed to the fact that the river was used 'frequently' as a play ground by children in the river basin (Danquah, 2010). The frequent usage of the river as a play ground exposes children to faecal oral diseases which they were most susceptible to due to their low resistance levels (Cairncross \& Ouano, 1990). This confirms the findings of an earlier study of villages downstream of Kumasi which showed that children swam in polluted rivers. Children were reported to suffer the most from diseases such as dysentery, cholera and bilharzia (McGregor et al., 2000).

\section{Conclusions}

In conclusion, this study established that the Aboabo River was bacteriologically polluted. Excessive faecal coliform counts revealed pollution from anthropogenic activity. These anthropogenic activities included indiscriminate dumping of refuse into the Aboabo River, channelling of raw sewage into the Aboabo River, open defecation along the banks of the Aboabo River and discharge of untreated effluents into the Aboabo River by the small scale industries. The direct anthropogenic activities were the result of the interplay of factors such as population growth, and institutional constraints. This study confirms similar research carried out in Nigeria (Ibe \& Njemanze, 1998) and Ethiopia (Jonnalagadda \& Mhere, 2001).

Secondly, the research has demonstrated that human activity impairs the quality of the Aboabo River and the local authorities need to urgently address this problem. Urban centres in Ghana are growing and if sanitation infrastructure demands are not met with appropriate institutional commitments and supported with attitudinal changes from residents, the environment as a whole and rivers in particular will be degraded through pollution. River pollution not only has negative implications for amenity but poses a significant risk to human health as well.

\section{Recommendations}

We recommended that not only should drainage systems be adequately provided in the river basin but the provision of such drainage systems must be supported with the enforcement of all by-laws. Adequate sanitation 
infrastructure must be provided together with education. The role of opinion leaders like Chiefs, Imams, priests and teachers must be emphasised. Opinion leaders in the various communities must partner with government and NGOs in the water and sanitation sectors to drive positive behavioural changes amongst all stakeholders.

\section{Acknowledgement}

The writers wish to acknowledge the contributions of Dr. David Satterthwaite of the International Institute of Environment and Development (IIED) and Dr. Duncan McGregor of the Royal Holloway University for providing reading material which helped to enrich the study. Our appreciation also goes to Mr. Kingsley Osei-Bonsu of the UNESCO IHE Lab, Department of Civil Engineering, KNUST for his assistance in the water quality analysis.

\section{References}

Abdul-Razak, A., Asiedu, A. B., Entsua-Mensah, R. E. M. \& deGraft-Johnson, K. A. A. (2009). Assessment of the water quality of the Oti River in Ghana. West African Journal of Applied Ecology. Vol.15.

Ayoade, J. O. (1988). Tropical hydrology and water resources. London: Macmillan Publishers Limited.

Cairncross, S. \& Ouano, E. A. R. (1990). Surface water drainage in urban areas. In Hardoy E.J. Cairncross, S. \& Satterthwaite D. (Eds.). The Poor Die Young: Housing and Health in Third World Cities (pp. 158-168). London: Earthscan publications.

CEDAR (1999). Peri-urban natural resources management at the watershed level, Kumasi, Ghana. Peri-urban interface production systems research, Centre for Developing Areas Research (CEDAR), Department of Geography, Royal Holloway, University of London UK, Inception report.

Cornish, G. A., Mensah, E. \& Ghesquire, P. (1999). Water quality and peri-urban irrigation: An assessment of surface water quality for irrigation and its implications for human health in the peri-urban zone of Kumasi, Ghana. Report OD/TN 95, HR Wallingford, UK.

Dix, H. M. (1981). Environmental pollution: atmosphere, land, water and noise. New York: John Wiley and Sons Limited.

Danquah, L. (2010). The causes and health effects of river pollution: A case study of the Aboabo River, Kumasi (Unpublished master's thesis). Kwame Nkrumah University of Science and Technology, Kumasi, Ghana.

GEPA (2009) GEPA Guidelines on effluent quality for discharge into natural waters. Kumasi: Ghana Environmental Protection Agency.

GSS (2005). 2000. Population and housing census: Ashanti Region analysis of district data and implications for planning. Accra: Ghana Statistical Service.

Hardoy, E. J., Mitlin, D. \& Satterthwaite, D. (2001). Environmental problems in an urbanizing world. London: Earthscan.

Hroncich, J. A. (1999). Surface water. In Letterman, R.D. (Ed.). Water quality and treatment: A handbook of community water supplies (pp. 47-64). American Water Works Association, New York: McGraw-Hill.

Ibe, K. M. \& Njemanze, G. N. (1998). The impact of urbanization and protection of water resources, Owerri, Nigeria. Journal of Environmental Hydrology. 6 (9), 1-9. Retrieved from http://www.hydroweb.com.

Jonnalagadda, S. B. \& Mhere, G. (2001). Water quality of the Odzi River in the Eastern Highlands of Zimbabwe. Water Research. 35 (10) 2371-2376. http://dx.doi.org/10.1016/S0043-1354(00)00533-9

Keraita, B., Drechsel, P. \& Amoah, P. (2003). Influence of urban wastewater on stream water quality and agriculture in and around Kumasi, Ghana. Environment and Urbanization. 15 (2), 171-178, http://dx.doi.org/10.1177/095624780301500207

KMA (2006). KMA Medium term development plan 2006-2009. Kumasi: Kumasi Metropolitan Assembly.

KMA (1998). Ghana local government bulletin, Friday 31 $1^{\text {st }}$ December, 1998. No 20. Kumasi: Kumasi Metropolitan Assembly, Kumasi.

McGregor, D., Thompson, D. A. \& Simon, D. (2000). Water quality and management in peri-urban Kumasi, Ghana. Land-Water linkages in rural watersheds electronic workshop. Case study 16. Rome: Food and Agriculture Organization.

McGregor, D., Thompson, D. A., Simon, D., Kotei, N. O. \& Poku, K. O. (2003). The influence of Kumasi on peri-urban water quality: a problem of community health and floodplain agriculture? In Cornish, G. (Ed.). 
Informal peri-urban irrigated agriculture: opportunities and constraints (pp. 65-76). Wallingford, England: HR Wallingford Ltd.

Meyer, F. P. \& Barclay, L.A (1990). Field manual for the investigation of fish kills. Washington D.C.: U.S. Fish and Wildlife Service. Resource Publication 177.

Obuobie, E., Keraita, B., Danso, G., Amoah, P., Cofie, O. O., Raschid-Sally, L. \& Drechsel, P. (2006). Irrigated urban vegetable production in Ghana: Characteristics, benefits and risks. Accra: International Water Management Institute.

Omane, O. K. (2002). Peri-urban water quality monitoring in the Sisa-Oda catchment of Kumasi (Unpublished master's thesis). Kwame Nkrumah University of Science and Technology, Kumasi, Ghana.

Saunders, M., Lewis, P. \& Thornhill, A. (2007). Research methods for business students (4 ${ }^{\text {th }}$ ed.). Essex: Pearson Education Limited.

Shaw, E. M. (1994). Hydrology in practice. (3rd ed.). London: Chapman and Hall.

UNESCO (2003). Water for people, water for life: UN world water development report, executive summary. Paris: United Nations Educational, Scientific and Cultural Organization.

UNICEF (2008). UNICEF Handbook on water quality. New York: United Nations Children's Fund.

WHO. (2006). Guidelines for drinking water quality: First addendum to third edition. Vol.1 recommendations. Geneva: World Health Organization.

Table 1. Distribution of study communities and their respective household samples selected for study

\begin{tabular}{|c|c|c|c|c|}
\hline Community & $\begin{array}{l}\text { Population } \\
\text { (2000) }\end{array}$ & $\begin{array}{l}\text { Total Number of Households } \\
\qquad(2000)\end{array}$ & $\begin{array}{c}\text { Percentage } \\
(\%)\end{array}$ & $\begin{array}{l}\text { Sample Selected } \\
\text { from community. }\end{array}$ \\
\hline \multicolumn{5}{|c|}{ Selected communities upstream } \\
\hline Pankrono & 36683 & 6591 & 17 & 67 \\
\hline Moshie Zongo & 34980 & 6794 & 17 & 67 \\
\hline Buokrom & 12374 & 2235 & 6 & 24 \\
\hline \multicolumn{5}{|c|}{ Selected communities midstream } \\
\hline Dichemso & 21281 & 4156 & 10 & 40 \\
\hline Aboabo & 34206 & 6626 & 17 & 67 \\
\hline \multicolumn{5}{|c|}{ Selected communities downstream } \\
\hline Asokwa & 18747 & 3276 & 8 & 32 \\
\hline Atonsu & 45778 & 9763 & 25 & 99 \\
\hline Total & 204049 & 39441 & 100 & 396 \\
\hline
\end{tabular}

Source: Authors Field Survey, 2008 
Table 2. Characteristics of selected physical parameters

\begin{tabular}{cccccc}
\hline Physical Parameters & $\begin{array}{c}\text { Station (S1) } \\
\text { Max } \pm \text { Min }\end{array}$ & $\begin{array}{c}\text { Station (S2) } \\
\text { Max } \pm \text { Min }\end{array}$ & Mean & $\begin{array}{c}\text { Standard } \\
\text { Deviation }\end{array}$ & $\begin{array}{c}\text { Guideline } \\
\text { Values* }\end{array}$ \\
\hline Temperature ${ }^{\circ} \mathrm{C}$ & $27.0 \pm 27.0$ & $27.3 \pm 27.2$ & 27.1 & 0.15 & - \\
$\mathrm{pH}$ & $7.39 \pm 6.75$ & $7.36 \pm 7.20$ & 7.2 & 0.295353 & $\begin{array}{c}6.5-9.5 \\
\text { Color (Hazen's H) }\end{array}$ \\
Conductivity $\mu \mathrm{s} / \mathrm{cm}$ & $1060 \pm 1403$ & $1205 \pm 927$ & 1148.75 & 204.0071 & $\begin{array}{c}\text { No visible } \\
\text { Colour }\end{array}$ \\
Total hardness $\mathrm{mg} / \mathrm{c} / \mathrm{cm}$ \\
DO $\mathrm{mg} / \mathrm{l}$ & $112 \pm 76$ & $120 \pm 72$ & 190.0 & 24.5221 & - \\
\hline
\end{tabular}

*WHO 2006

- No health based guideline value was proposed by WHO 2006

Table 3. Characteristics of selected chemical parameters

\begin{tabular}{cccccc}
\hline Chemical Parameters & $\begin{array}{c}\text { Station }(\mathrm{S} 1) \\
\text { Max } \pm \text { Min }\end{array}$ & $\begin{array}{c}\text { Station }(\mathrm{S} 2) \\
\text { Max } \pm \text { Min }\end{array}$ & Mean & $\begin{array}{c}\text { Standard } \\
\text { Deviation }\end{array}$ & $\begin{array}{c}\text { Guideline } \\
\text { Value }\end{array}$ \\
\hline TDS mg/l & $709 \pm 530$ & $606 \pm 468$ & 582.75 & 103.8408 & $1200 \mathrm{mg} / \mathbf{l}^{*}$ \\
TSS mg/l & $2495 \pm 209$ & $208 \pm 186$ & 792.5 & 1135.705 & $50^{\#}$ \\
Phosphate mg/l & $30.8 \pm 16.6$ & $18.8 \pm 10.6$ & 19.2 & 8.474275 & - \\
Sulphate mg/l & $25 \pm 10$ & $72 \pm 40$ & 36.75 & 26.5 & - \\
Nitrate mg/l & $12.5 \pm 1.1$ & $10.0 \pm 1.0$ & 6.15 & 5.9769 & $50^{*}$ \\
Calcium mg/l & $12.83 \pm 9.6$ & $11.2 \pm 8.2$ & 10.5 & 2.000973 & - \\
Magnesium mg/l & $21.4 \pm 10.70$ & $22.4 \pm 12.64$ & 16.8 & 5.973126 & - \\
BOD mg/l & $720 \pm 280$ & $320 \pm 300$ & 405 & 210.634 & $50^{\#}$ \\
COD mg/l & $2832 \pm 520$ & $536 \pm 464$ & 1088 & 1163.076 & $250^{\#}$ \\
\hline
\end{tabular}

*WHO 2006; \#GEPA 2009

- represents no guideline value set by WHO 2006 or GEPA 2009. 
Table 4. Characteristics of selected bacteriological parameter

\begin{tabular}{cccccc}
\hline $\begin{array}{c}\text { Bacteriological } \\
\text { Parameter }\end{array}$ & $\begin{array}{c}\text { Station (S1) } \\
\text { Max } \pm \text { Min }\end{array}$ & $\begin{array}{c}\text { Station (S2) } \\
\text { Max } \pm \text { Min }\end{array}$ & Mean & $\begin{array}{c}\text { Standard } \\
\text { Deviation }\end{array}$ & $\begin{array}{c}\text { Guideline } \\
\text { Value }\end{array}$ \\
\hline $\begin{array}{c}\text { Faecal Coliform } \\
\text { N/100 }\end{array}$ & $4 \times 10^{6} \pm 3 \times 10^{6}$ & $4 \times 10^{6} \pm 3 \times 10^{6}$ & $3.5 \times 10^{6}$ & 577350.3 & $0 *$ \\
\hline
\end{tabular}

*WHO 2006

Table 5. Most frequent method of garbage disposal by households

\begin{tabular}{cc}
\hline Frequent means of garbage disposal & Percentage of households* \\
\hline Dumped into or near river & 44 \\
Dumped into public container & 25 \\
Dumped into open space & 11 \\
Burnt & 5 \\
Collected by individual sanitation & 5 \\
contractors & 4 \\
Buried & 4 \\
Cannot tell & 2 \\
Door or Door collection by KMA & 100 \\
\hline All
\end{tabular}

*Sample Size: 396 households

Table 6. Primary means of excreta disposal by households

\begin{tabular}{cc}
\hline Primary Means of excreta disposal & Percentage of households* \\
\hline Into septic tanks & 72 \\
Into Gutters & 13 \\
Chanelled into the Aboabo river & 6 \\
Cannot tell & 4 \\
Declined to respond & 3 \\
Onto street & 1 \\
Other means & 1 \\
\hline All & 100
\end{tabular}

*Sample Size: 396 households 


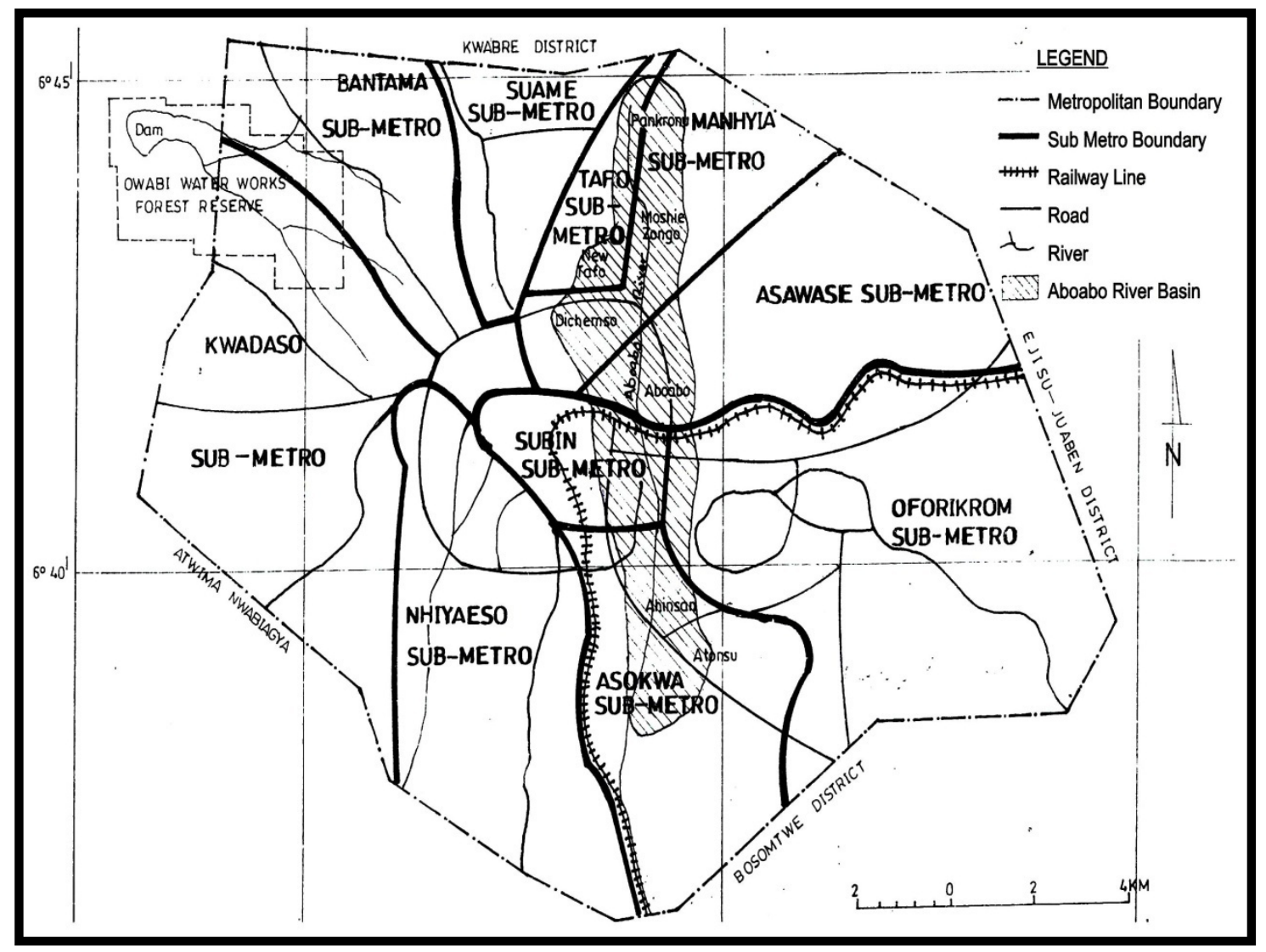

Figure 1. Map showing the Kumasi sub-metros and the Aboabo river basin 


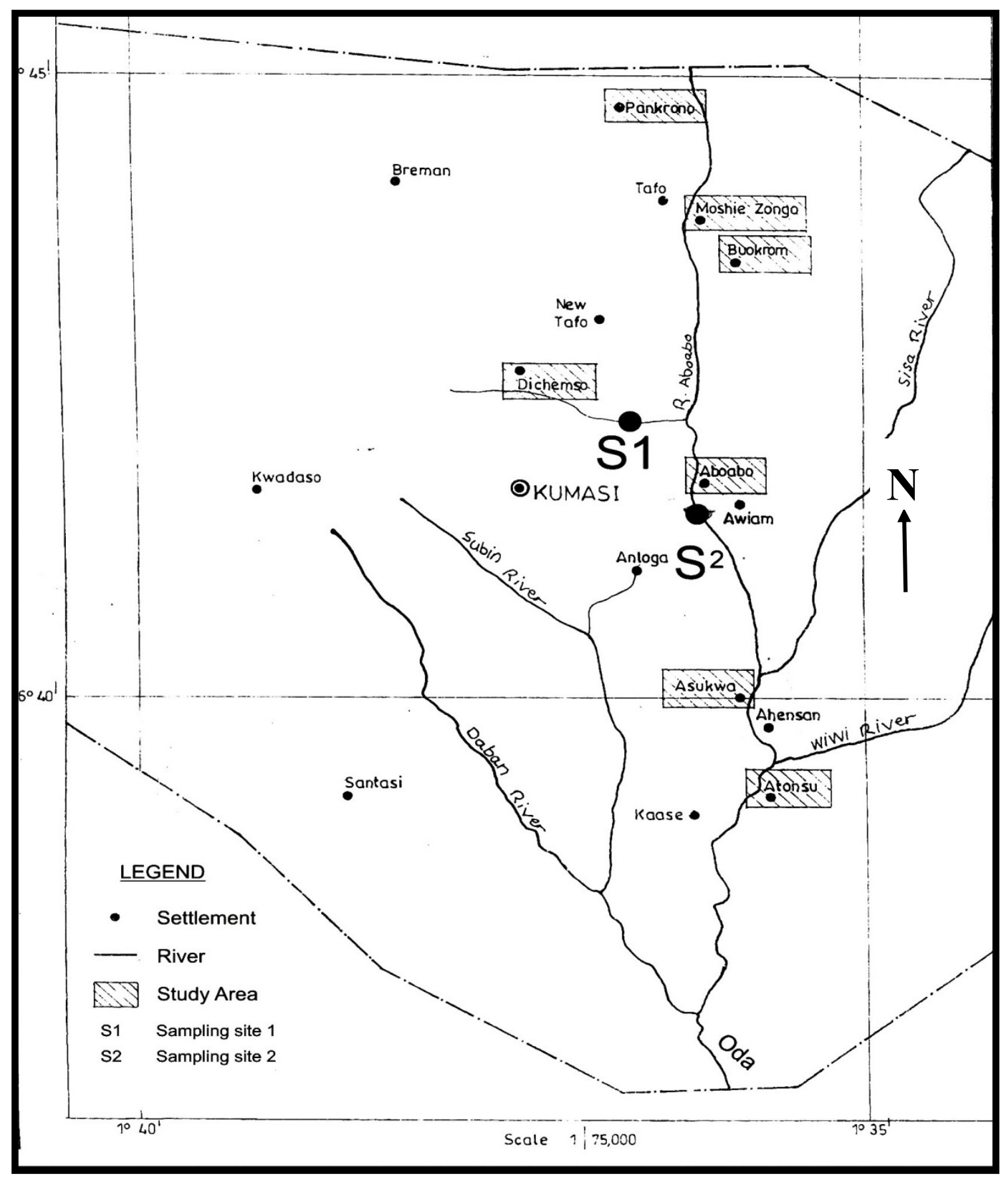

Figure 2. A drainage map of Kumasi showing the location of sampling sites and study communities 


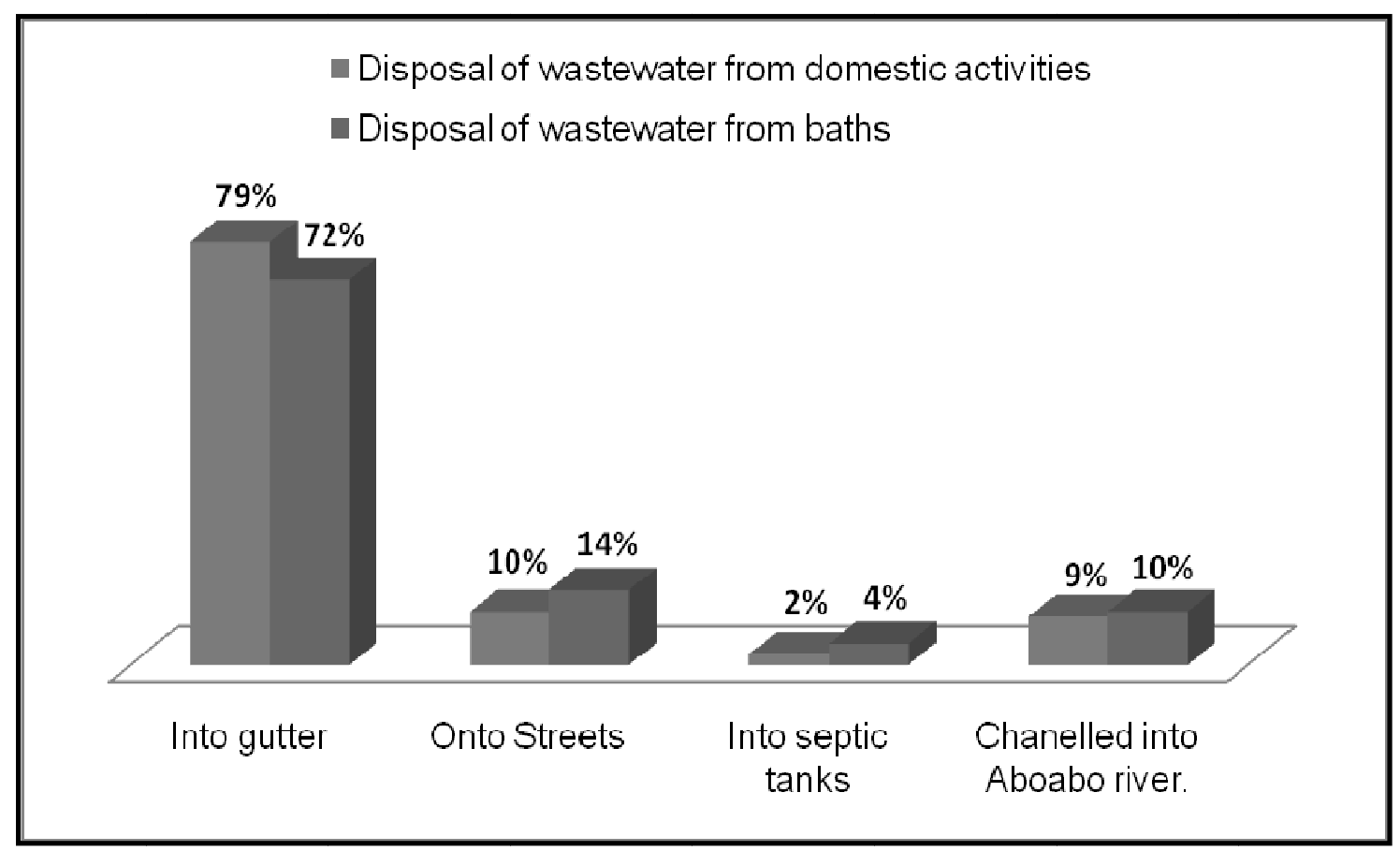

Figure 3. Primary means of disposal of liquid waste by households

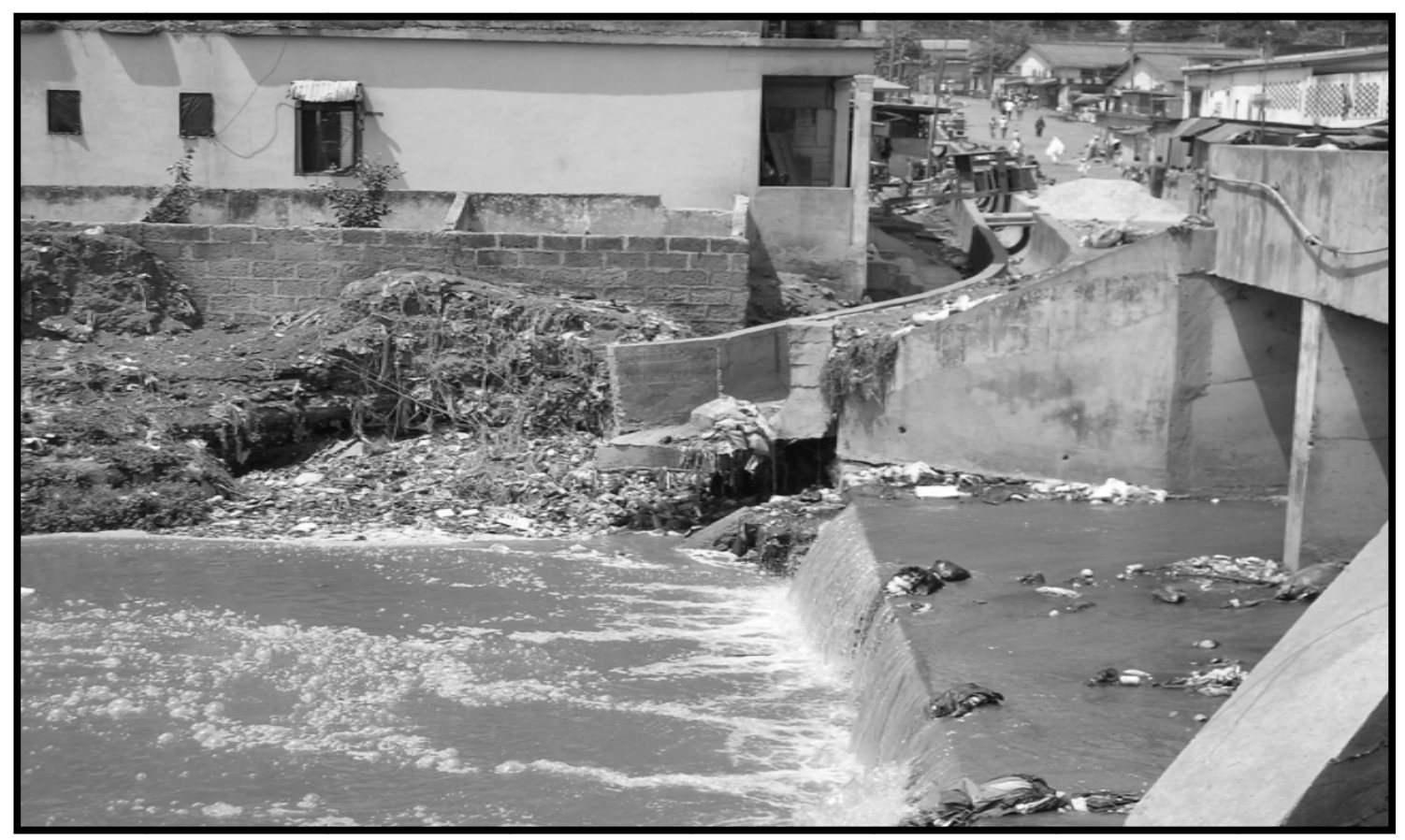

Figure 4. A drain empties waste water with refuse into the Aboabo River - Royal Bridge, Aboabo, September 2009 


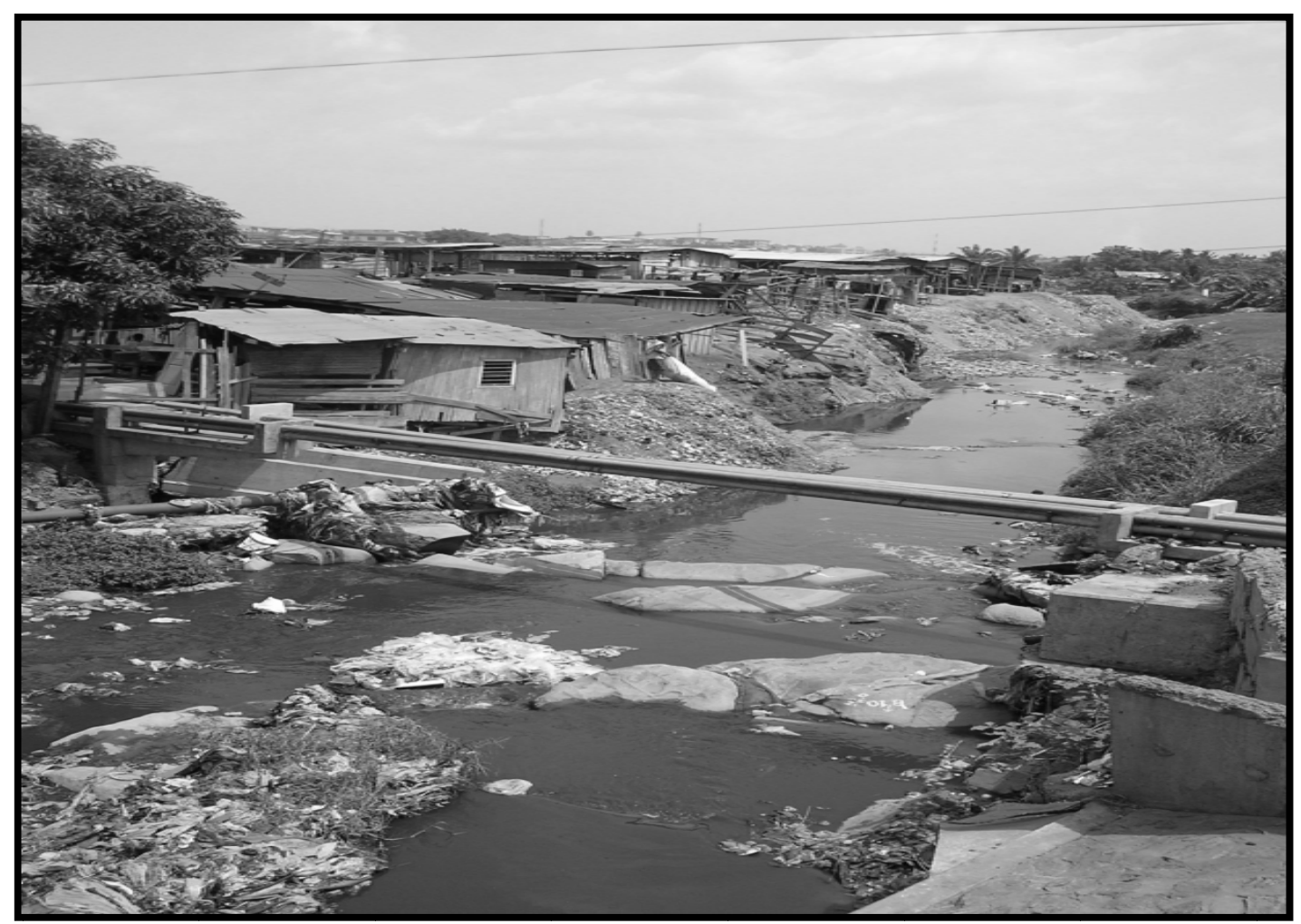

Figure 5. Wood processing on the banks of the Aboabo River, September 2009 